\title{
FACTORS ASSOCIATED WITH SUSTAINABILITY OF INTEGRATED GERIATRIC HEALTH POST IN TABANAN, BALI
}

\author{
Indra Peratiwi, Hesteria Friska Armynia Subratha
}

\author{
District Health Office Tabanan, Bali \\ School of Health Sciences Advaita Medika, Bali
}

\begin{abstract}
Background: Much has been written recently about the need to develop more integrated care for older people. The term comprehensive geriatric assessment, is a form of integrated care for older people that is used to describe the practice of specialist multidisciplinary assessment and management of predominantly frail older people. Medical and social care may be integratively associated within and outside of the health care sector. The societal idea of care of the elderly as part of a general welfare system may be seen as such integration. This study aimed to factors associated with sustainability of integrated geriatric health post in Tabanan, Bali.

Subjects and Method: A qualitative study was carried out at "posyandu lansia" (integrated geriatric health post), Tabanan, Bali. Key informants were selected for this study, including the elderly, village head, and a few community health center workers. The study theme was sustainability of integrated geriatric health post. The data were collected by in-depth interview, direct observation, and document review.

Results: From the health care provider perspective, the government had imposed the introduction of "posyandu lansia" (integrated geriatric health post). From the perspective of enabling factor, there was a need for the provision of human resources, facilities, and infrastructure, to establish and operate "posyandu lansia", and support from the community. From the perspective of the elderly, some did not visit "posyandu lansia" because they did not have enough time or they have felt security under the health insurance protection.

Conclusion: Sustainability of the integrated geriatric health post depends on the preparedeness of the human resources, availability of facilities and infrastructure, and support from the community.
\end{abstract}

Keywords: integrated geriatric health post, sustainability.

\section{Correspondence:}

Indra Peratiwi. District Health Office Tabanan, Bali.

Email: indra.peratiwi2013@gmail.com. Mobile: 082236614502

The 4th International Conference on Public Health 